\title{
The Effect of Styrofoam Addition into HRS-Base on Marshall Characteristics
}

\author{
Elsa Eka Putri ${ }^{\#}$, Ariefky Dwinanda ${ }^{\#}$ \\ ${ }^{\#}$ Civil Engineering Department, Engineering Faculty, University of Andalas, West Sumatera, Indonesia \\ Email: elsaeka@eng.unand.ac.id
}

\begin{abstract}
In this research, Styrofoam is added to the HRS-Base type of pavement to investigate the Marshall Parameter of its pavement mixture. Styrofoam is one type of waste that has characteristics that are nearly equal to asphalt, which are soften when heated and harden when temperatures return to normal. This study was conducted to determine the effect of Styrofoam on Hot Rolled Sheet-Base (HRS-Base) by varying the addition of Styrofoam in the mix. Based on the research, it can be concluded that the use of asphalt with the addition of Styrofoam as much as $0.5 \%, 1 \%$, and $1.5 \%$ by weight of asphalt in an HRS-Base mixture improves the Stability of the mixture. The value of Flow is also increases when compared with asphalt mixture without Styrofoam. Asphalt mixture with the addition of Styrofoam as much as $1.5 \%$ has a maximum Stability above $1500 \mathrm{~kg}$ with optimum binder content is at $7.4 \%$, and the value of Flow is above $3 \mathrm{~mm}$. The $1.5 \%$ Styrofoam Asphalt ratio having the value of Voids in the Mixture is $4 \%$, the Void in Mineral Aggregate is $19.2 \%$, the Void Filled with Asphalt is 80\%, and the Marshall Quotient is $260 \mathrm{~kg} / \mathrm{mm}$.
\end{abstract}

Keywords: flexible pavement; hot rolled sheet-base (HRS-Base); styrofoam; marshall parameters.

\section{INTRODUCTION}

HRS-Base is pavement type which had a gap grading gaps. It is mixed, spread, and compacted in hot conditions at a given temperature. The function of asphalt on the flexible pavement is to bind the aggregate which will form asphalt pavement construction, so the ability to bind the aggregate is an important parameter to be considered. Styrofoam or foamed polystyrene (FPS) is lightweight, compact and categorized as plastic. Styrofoam as well as plastics has many benefits and commonly used for daily activities. Such as food and fruits packaging, electronic buffer, and it is known as the cork is indeed practical, lightweight, relatively leak proof and can keep the temperature of the food properly. This is what makes this material well-liked and widely used, including in the instant food industry.

Styrofoam is the brand name for polystyrene foam. Styrofoam is a plastic made from petroleum, styrene monomer by suspension polymerization at a certain pressure and temperature, further heating to soften the resin and evaporating the residual blowing agent. The basic material used is $90-95 \%$ and $5-10 \%$ polystyrene gases such as nbutane or n-pentane [1]. Furthermore, Styrofoam is actually no less dangerous than plastic.

Styrofoam is harmful to the body as well as plastics when using it as food container and harmful to the environment when disposed to landfill. Styrofoam produces styrene oxide which may increase the carcinogenic production, especially when they used as warm food or drink container as well as, oils, acidic foods and alcohol causing human contamination and pose a health risk to people [2].

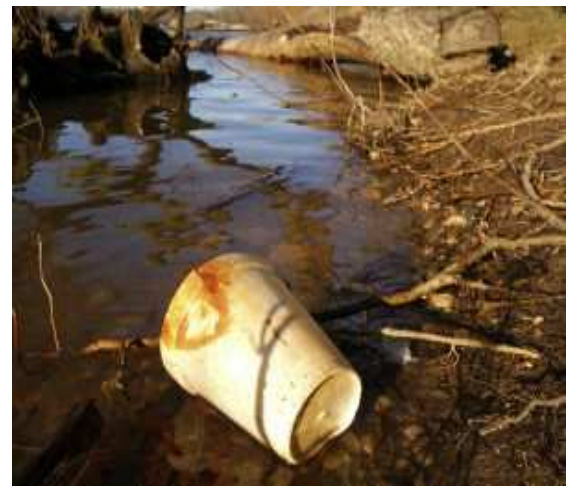

Fig.1 Styrofoam remains on its shape Credit: Rebecca Grabill E+ Getty Images

Styrofoam waste is increasing from time to time because Styrofoam waste cannot be easily recycled. If the plastic waste takes up to 500 years to decompose in the soil. So, the Styrofoam waste will remain on its shape, does not change or disappear until the end of life as shown in Figure 1. 


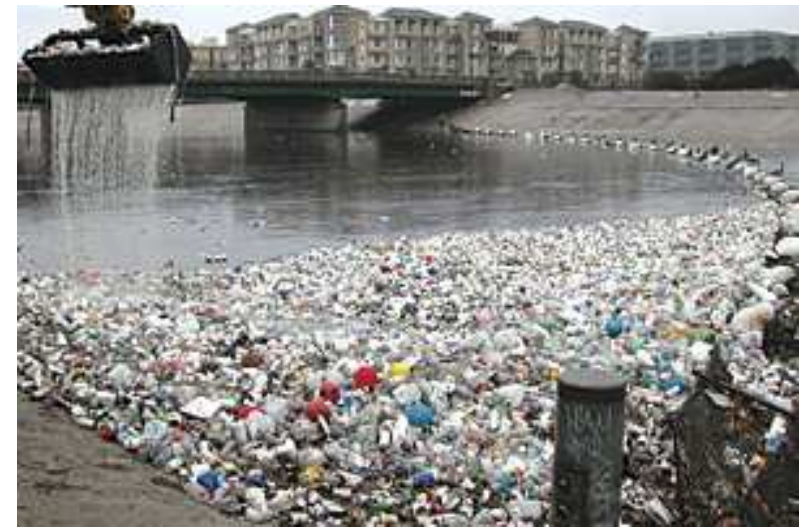

Fig.2 Styrofoam and Plastic waste in Indonesia River

Several efforts of reducing waste products have been investigated. For instances, producing biodegradable plastics, or using alternative materials such as natural lime in order to reduce the cement replacement [3], [4]. The research of using Styrofoam as an alternative material for pavement strengthening is expected to reduce the waste instead of disposing to the landfill. The Styrofoam used in this study is shown in Fig. 3, while the Styrofoam that has been shredded is shown in Fig. 4.

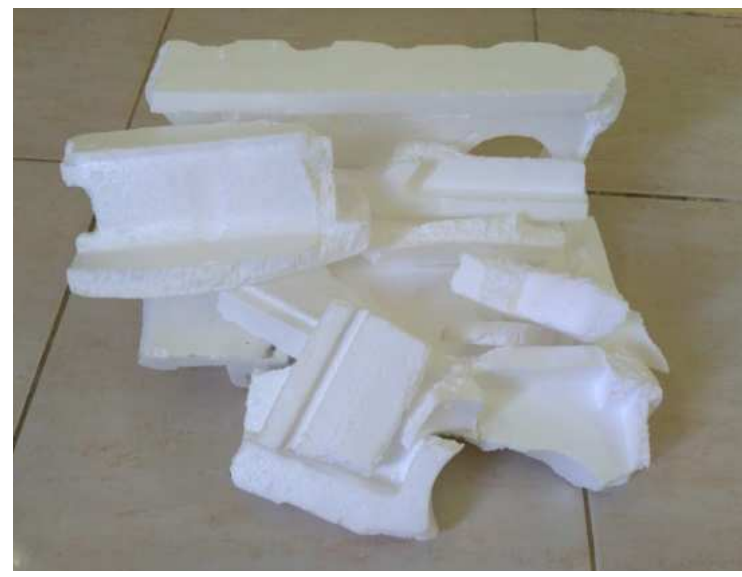

Fig.3 Styrofoam from Electronic Safety Packaging

HRS-Base flexible pavement is one type of pavement structure with asphalt as an aggregate binder. Flexible pavement structure consists of several layers that are subgrade, subbase, base, and surface at the top of the pavement. The surface is asphalt pavement mixed with coarse aggregate, fine aggregate, and bitumen. One of the efforts of increasing flexible pavement performance is to increase the aggregate binding.

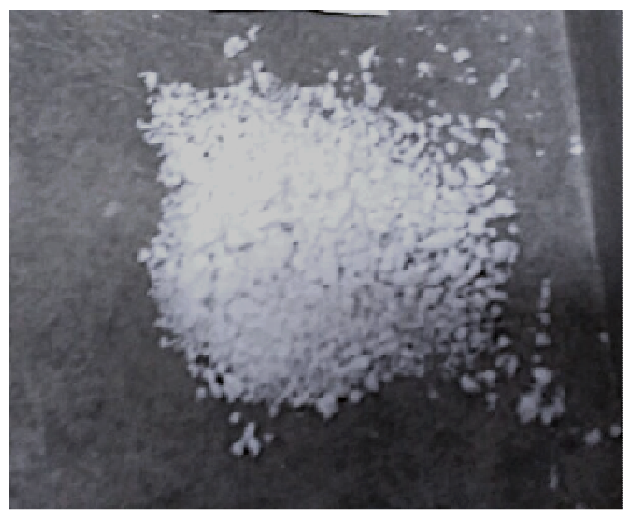

Fig.4 Shredded Styrofoam

Styrofoam or bubble plastics were investigated as bitumen additives to form a new binder for pavement structure due to its behavior more likely bitumen. It is hard in low temperature and softens when the temperature is increased. Styrofoam is being added to the bitumen aggregate mixture. In doing so, the strength of the flexible pavement may increase. The investigation of optimum Styrofoam usage into the bitumen was by Marshall test methods as per 2010 specification 6th division from Public Work Department standard in Indonesia, i.e., high Stability, Flow, Void in the mixture, Void in Mineral Aggregate and Marshall Quotient that meet based on this standards requirement [5]. The aim of this research is to investigate the effect of Styrofoam addition to the bitumen to form a Hot Rolled Sheet-Base Course (HRS-Base) mixture using several testings' in the lab.

\section{A. Literature Review}

Many efforts have been done to improve the quality of pavement structure, such as base course strengthening using geogrid [6], embankment or subgrade strengthening using coal ash mixture [7] or using the special material added to the asphalt. Plastics are high demand materials, employed in a wide range of applications, from household packaging, agricultural, automotive, to building construction, due to their lightweight characteristics, high chemical Stability, and low degradability. The main application of the Styrofoam as seen in Fig. 3 is as an electronic safety packaging. The use of Styrofoam in this investigation is due to its behavior more likely bitumen, that is melted if burning it and hardened when the temperature is decreased.

Moreover, the HRS-Base is one of the flexible pavement types. The use of HRS-Base as flexible pavement depends on the material available locally. It consists of coarse aggregate, fine aggregate, and filler. Coarse aggregate is grains of crushed stone, gravel, sand, and other minerals, whether from natural or human-made in the form of solid minerals whether a large size, or small, or fragments [8]. Based on Indonesian Standard, coarse aggregate is retained at the sieve size No.4 $(4.75 \mathrm{~mm})$, fine aggregate is passing No.4 while the filler is in the form of stone ashes or limestone ash which agree with AASHTO M303-89 [9].

The color of bitumen is black, when it was warm, is sticky. Bitumen was visco-elastic material or semi-solid form of petroleum and solid or semi-solid in room temperature [10]. If the temperature raises the bitumen is 
melted and if the temperature decreases the bitumen will become a solid again due to the thermoplastic behavior of the bitumen.

Styrofoam is a type of plastic made from $90 \%-95 \%$ polystyrene and $5 \%-10 \%$ of gases such as n-butane or npentane, which are widely used as protective and retaining vibration items such as for electronic goods. The use of Styrofoam as additives is due to having thermoplastics behavior that is a stable room temperature and melted if heated above about $100{ }^{\circ} \mathrm{C}$. Styrofoam becomes rigid again when cooled.

On the other hand, Styrofoam resists acid, alkaline, and another corrosive behavior. One of the functions of Styrofoam is as an adhesive when mixed with gasoline. Consequently, as bitumen is an aromatic hydrocarbon, then the addition of Styrofoam into the bitumen is expected to improve the adhesion between the aggregate and bitumen. Thus it will improve the quality of pavement mixture that meets the requirements by the Ministry of Public Works General Directorate of Highways [5]. In doing so, the waste Styrofoam that to dispose of the landfill is reduced.

The investigation of the use of Styrofoam addition to the Asphalt Concrete pavement mixture achieved its optimum Marshall parameter at $6 \%$ bitumen content, where the variations are $0 \%, 0.01 \%, 0.015 \%, 0.02 \%, 0.025 \%$ with the bitumen content 5\%, 5.5\%, 6\%, 6.5\%, 7\% [11]. Moreover, Styrofoam has higher tensile strength so it can improve the strength, especially the elasticity of bitumen [12].

Furthermore, the investigation of the use of Styrofoam on Porous Asphalt pavement achieved its Marshall requirement specification at $6.26 \%$ and $9 \%$ Styrofoam addition except for the Stability which is only $495.92 \mathrm{~kg}$. It is slightly below the specifications required by the Australian Asphalt Pavement Association (1997) that a minimum of $500 \mathrm{~kg}$ [13].

Thus, the investigation of the use of Styrofoam is continued to HRS-Base pavement type to see its suitability to generate a more stable pavement. In doing so, it can also be protecting the environment by reducing the amount of waste Styrofoam.

HRS-Base is applied for surface pavement under HRSWearing Coarse layers for flexible pavement. HRS-Base is pavement type which had a gap grading gaps. In order to investigate its Marshall properties that use Styrofoam in its binder, thus several samples were produced then tested by Marshall Test in Lab. Some of the Marshall parameters that have been investigated are Stability, Flow, Marshall Quotient, Void in Mineral Aggregate, Void in Mix and so on to obtain the optimum bitumen content that meets the requirements as can be seen in Table 1 .

From the requirements of the HRS-Base as shown in Table 1, the stability of the pavement should be more than $800 \mathrm{~kg}$, with the number of blows on each face is 75 blows. Marshall Quotient minimum is $250 \mathrm{~kg}$. Moreover, the minimum void in the mixture, in mineral aggregate, and filled with bitumen were $4 \%, 18 \%$ and $68 \%$ respectively to ensure the durability, stiffness and stability to resists the deformation due to traffic loads.
TABLE I

MARSHALl PARAMETER REQUIREMENTS

\begin{tabular}{|c|c|c|}
\hline \multicolumn{2}{|c|}{} & \multicolumn{2}{c|}{$\begin{array}{c}\text { HRS } \\
\text { Marshall Parameter Properties }\end{array}$} & $\begin{array}{c}\text { Wearing } \\
\text { Coarse }\end{array}$ & $\begin{array}{c}\text { Base } \\
\text { Coarse }\end{array}$ \\
\cline { 3 - 4 } & & 75 \\
\hline No. of blows on each face & & 4 \\
\hline Void in Mix (\%) & Min. & 6 \\
\cline { 2 - 3 } & Maks. & 18 \\
\hline Void in Mineral Aggregate (\%) & Min. & 68 \\
\hline Void Filled with Bitumen (\%) & Min. & 800 \\
\hline Marshall Stability (kg) & Min.. & 3 \\
\hline Flow (mm) & Min. & 250 \\
\hline Marshall Quotient $(\mathrm{kg} / \mathrm{mm})$ & Min. & \multicolumn{2}{|c|}{} \\
\hline
\end{tabular}

To determine the optimum content of bitumen the maximum stability and maximum unit weight were chosen as well as the median limits for VIM and VFA [9].

\section{MATERIAL AND METHOD}

For the most part, Hot Rolled Sheet-Base mix design procedures (the 6th division specification from Public Work Department standard in Indonesia) and applicable AASHTO and ASTM testing standards for the Marshall Sample and Testing Procedure were followed [5]. The materials used for the research consists of coarse aggregates, fine aggregates, Cement filler, Styrofoam and bitumen. The mineral fillers used are the Portland Cement. The 85-100 penetration grade bitumen was chosen for the study. The samples were prepared at four different percentages of Styrofoam in bitumen, i.e. $0 \%, 0.5 \%, 1 \%$ and $1.5 \%$ to form a new binder. The properties of the binder and its physical properties are listed in Table 2. There are three quantified samples at each percentage then the results are presented in the average value.

TABLE II

BITUMEN PROPERTIES

\begin{tabular}{|c|c|c|c|c|}
\hline \multirow{2}{*}{$\begin{array}{l}\text { Performance } \\
\text { Indexes }\end{array}$} & \multicolumn{4}{|c|}{ Styrofoam } \\
\hline & $0 \%$ & $0.5 \%$ & $1 \%$ & $1.5 \%$ \\
\hline $\begin{array}{l}\text { Penetration }\left(25^{\circ} \mathrm{C}, 100\right. \\
\text { gr, } 5 \mathrm{~s})(0.1 \mathrm{~mm})\end{array}$ & $87 \mathrm{~mm}$ & $95 \mathrm{~mm}$ & $98 \mathrm{~mm}$ & $92 \mathrm{~mm}$ \\
\hline Unit Weight $\left(25^{\circ} \mathrm{C}\right)$ & 1.041 & 1.025 & 1.006 & 1.014 \\
\hline $\begin{array}{c}\text { Flash Point (Cleveland } \\
\text { Open Cup) } \\
\end{array}$ & $236^{\circ} \mathrm{C}$ & \multicolumn{3}{|c|}{$318^{\circ} \mathrm{C}$} \\
\hline Burning Point $\left({ }^{\circ} \mathrm{C}\right)$ & $327^{\circ} \mathrm{C}$ & \multicolumn{3}{|c|}{$338^{\circ} \mathrm{C}$} \\
\hline $\begin{array}{l}\text { Softening Point (Ring } \\
\text { and Ball Test) }\end{array}$ & $54.5^{\circ} \mathrm{C}$ & $53.5^{\circ} \mathrm{C}$ & $52.5^{\circ} \mathrm{C}$ & $56.5^{\circ} \mathrm{C}$ \\
\hline $\begin{array}{l}\text { Lost on Heating } \\
\left(163^{\circ} \mathrm{C}, 5 \text { hours }\right)\end{array}$ & 0.05 & 0.03 & 0.015 & 0.02 \\
\hline $\begin{array}{l}\text { Penetration due to Loss } \\
\text { on heating }\left(25^{\circ} \mathrm{C}, 100\right. \\
\text { gr, } 5 \mathrm{~s})(0.1 \mathrm{~mm})\end{array}$ & $71 \mathrm{~mm}$ & $75 \mathrm{~mm}$ & $81 \mathrm{~mm}$ & $85 \mathrm{~mm}$ \\
\hline
\end{tabular}

\section{A. Sample Preparations}

The mixes studied were compacted to 75 blows on each surface of the Marshall sample [5]. The bitumen is heated to a temperature of $90^{\circ} \mathrm{C}$ then the shredded Styrofoam as seen in Fig. 2, was mixed with bitumen conventionally. It is stirred for 5 minutes until completely mixed. The mixed 
temperature of $90^{\circ} \mathrm{C}$ is hot enough to make a solid mixture, and does not exceed the weight loss tests temperature of 163oC (ASTM D 2872), so the content of the bitumen does not change due to heating [5][14]. The type of pavement used to investigate the Styrofoam usage is a flexible pavement, Hot Rolled Sheet-Base. Moreover, Styrofoam variations are $0 \%, 0.5 \%, 1 \%$, and $1.5 \%$ by total weight of bitumen.

\section{B. Test Performed}

The tests were performed at civil engineering laboratory for highway engineering at Andalas University. Aggregate and bitumen were available at the lab. Both aggregate and asphalt were examined of their properties as pavement materials, before mixing it in order to produce a high-quality pavement mixture as per the Public Work Department standard in Indonesia specification [5].

\section{1) Aggregate Testing}

- Specific Gravity (SNI 1969:2008/ SNI 1970: 2008)

The specific gravity of coarse aggregate is 2.60 with the absorption of $0.014 \%$ and for fine aggregate 2.47 with the absorption of $0.046 \%$. Based on the 2010 General Specification of Division 6 Revision 3, the specific gravity of the coarse and fine aggregates shall not differ by more than 0.2 and water absorption should be less than $3 \%$.

\section{- Volume Weight ((SNI 03-1970-1990)}

The volume weight was examined in order to determine the amount of aggregate to be used along the road. In doing so, the amount of aggregate can easily be measured by volume. Knowing the length and the width of the road and the thickness of the pavement, the amount of aggregate can be quantified.

\section{- Coating and Stripping of Bitumen-Aggregate} Mixture (SNI 03-2439-1991).

The allowable percentage of uncoated aggregate is $5 \%$ retained. In this investigation, for all the percentage of Styrofoam addition, there were $98 \%$ of the aggregate surface were coated by bitumen.

\section{- Los Angeles Abrasion Value} (SNI 2417: 2008)

The maximum loss value of Los Angeles Abrasion test is maxed $40 \%$. Thus, the aggregate used in this investigation was having $19.18 \%$ loss on abrasion.

\section{- Aggregate Impact Value (SNI 03-4426-1997)}

The value of the aggregate impact of $8.04 \%$ shows that the aggregate is strong enough that the value is lower than the maximum value of $30 \%$.

\section{2) Bitumen Testing}

- Loss on Heating (SNI 06-2440-1991) (max. 0.8\%). Loss on heating for $0 \%$ Styrofoam is $0.05 \%$, while for $0.5 \%, 1 \%$, and $1.5 \%$ Styrofoam their loss on heating were $0.03 \%, 0.015 \%$, and $0.02 \%$ respectively.
- Softening Point and Flash Point (SNI 06-24331991)

Softening Point for all the variation of Styrofoam addition was in the range $53^{\circ} \mathrm{C}-57^{\circ} \mathrm{C}$. According to SNI 06-2434-1991, the Softening Point should be in the range of $48^{\circ} \mathrm{C}-58^{\circ} \mathrm{C}$. Moreover, Flash Point for $0 \%$ Styrofoam in bitumen is $236^{\circ} \mathrm{C}$, and for bitumen with Styrofoam addition is $318^{\circ} \mathrm{C}$ for all the percentage Styrofoam in bitumen.

\section{- $\quad$ Penetration (SNI 06-2456-1991)}

The bitumen penetration results of all the percentage of Styrofoam addition were in the range of $7.0 \mathrm{~mm}$ $8.0 \mathrm{~mm}$.

Marshall parameters were used to determine the material suitability for pavement surface layer, and the value of all parameters was used to determine optimum bitumen content that achieves the maximum stability [5], [16]. Two critical properties are determined from the Marshall test, first is the maximum load the specimen can be carried before failure, which is known as the Marshall Stability and the amount of deformation of the specimen before failure occurred is known as the Marshall Flow.

Other Marshall parameters were also observed such Marshall Quotient, Void in Mixture, Void in Mineral Aggregate (VMA) and void filled with bitumen. The ratio of Stability to Flow is known as the Marshall Quotient. Marshall Quotient is a sort of pseudo stiffness which is a measure of the material's resistance to permanent deformation [17]. Stability of the pavement structure was used to determine the asphalt mixture characteristics. Asphalt pavement quality can be characterized by it is their stiffness, stability, durability, permeability, workability, fatigue resistance, skid resistance, and resistance to moisture damage [18].

The characteristics of the Styrofoam added to bitumen to form an HRS-Base pavement mixture was performed in the Civil Engineering laboratory in Andalas University. The results were then analyzed by the existing theory which accomplishes the specifications set by the Ministry of Public Works General Directorate of Highways, AASHTO, and ASTM standard [5].

\section{RESULTS AND DISCUSSIONS}

\section{A. Marshall Stability}

Marshall Stability test is the performance prediction measure conducted on the bituminous mix. Optimum bitumen content is an adequate amount of bitumen to ensure a durable pavement. The procedure consists of the determination of the properties of the mixture, Marshall Stability and Flow analysis and final determination of optimum bitumen content.

Properties of the HRS-Base mixture determine the proportion of aggregate and bitumen to produce the bituminous mix, which is then used for the Marshall properties determination. The Stability test results are shown in Fig. 5. The results show that for each percentage of Styrofoam the Stability increases with increasing bitumen 
content up to the optimum bitumen content and after that, the Stability of the mixtures decreases.

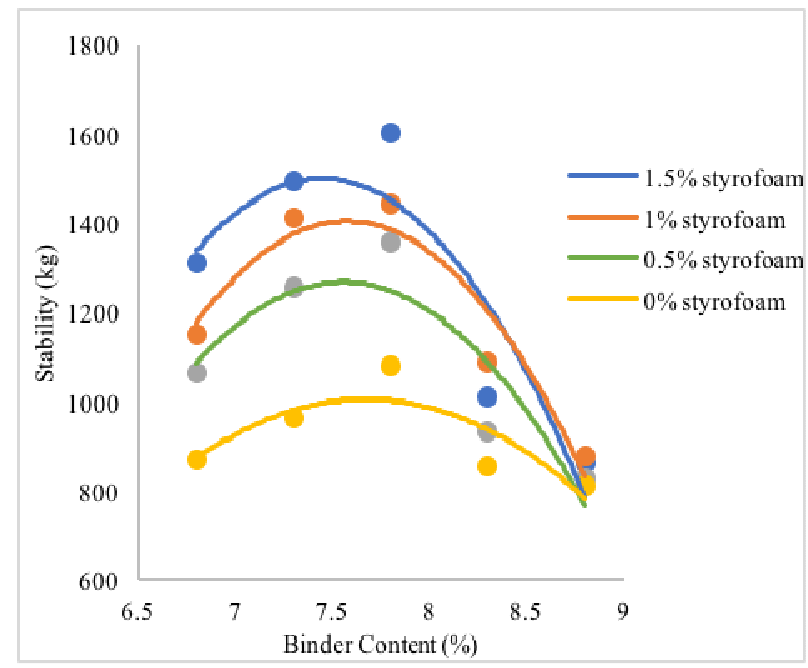

Fig.5 Stability (kg) vs Binder Content (\%)

The optimum bitumen content was found to be $7.7 \%$, $7.6 \%, 7.6 \%, 7.4 \%$ for $0 \%, 0.5 \%, 1 \%$, and $1.5 \%$ Styrofoam in bitumen respectively. By examining the plot at the point of optimum bitumen content, the stability values were estimated as $1000 \mathrm{~kg}, 1270 \mathrm{~kg}, 1400 \mathrm{~kg}$ and $1500 \mathrm{~kg}$ for $0 \%$, $0.5 \%, 1 \%$, and $1.5 \%$ Styrofoam respectively, all these values exceed the minimum requirement for high traffic [5].

It can be seen that the Stability values for all various Styrofoam addition mixtures met the SNI specification of not less than $800 \mathrm{~kg}$. The results indicate that the bitumen with Styrofoam addition can bind the HRS-base pavement mixture due to having better Stability value. The increase in Stability of the mixture can be attributed to improved adhesion between the aggregate and bitumen, having a longer service life and can carry the higher load of the vehicle.

\section{B. Flow}

Flow is the amount of deformation occurs in a layer of pavement due to withstanding the load received. The amount of deformation occurring in the pavement layer also affected by the value of VFB, VIM, and Stability. The Flow values of the Styrofoam variation against bitumen content are shown in Figure 6.

It can be seen that the Flow increased with increasing bitumen content. Moreover, increasing the Styrofoam content in the mixture resulted in increasing the Flow value too. At the optimum binder content of $7.7 \%, 7.6 \%, 7.6 \%$, $7.4 \%$ for $0 \%, 0.5 \%, 1 \%$, and $1.5 \%$ Styrofoam in bitumen respectively, the value of Flow of the mixture with Styrofoam was $4 \mathrm{~mm}, 6 \mathrm{~mm}, 6.2 \mathrm{~mm}$ and $7 \mathrm{~mm}$, with $1.5 \%$ Styrofoam showing the lowest values for Flow and having the highest the Stability. Increases in Flow value indicated a higher the amount of deformation before failures occur.

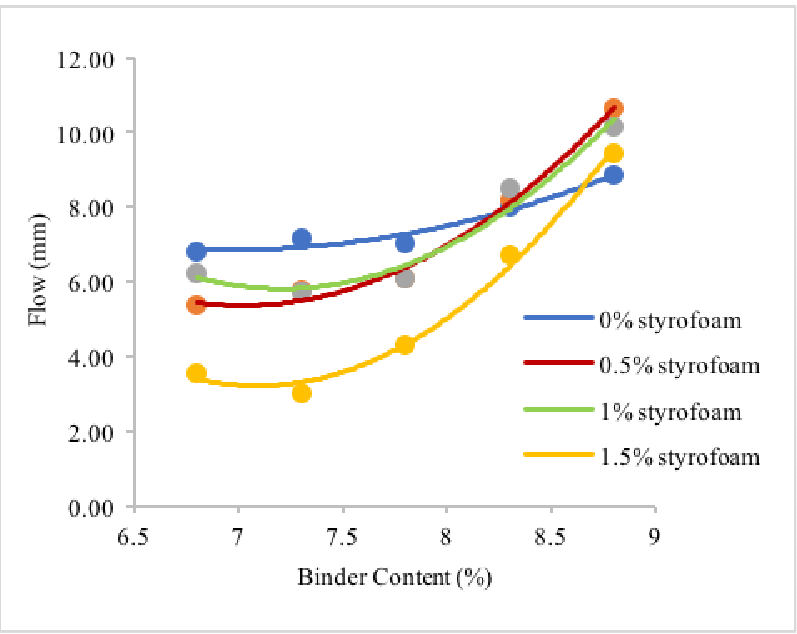

Fig.6 Flow (mm) vs. Binder Content (\%)

For $1.5 \%$ Styrofoam that is having the highest Flow, it may be due to the quantity of the Styrofoam used in the mixture, that soften the mixture but the mixture is stable. More tests like the repeated load axial test (RLAT), and wheel tracking test. that can evaluate the permanent deformation resistant of asphalt mixtures better would be carried out in future studies.

\section{Marshall Quotient}

Marshall Quotient represents the ratio of load to deformation. Marshall Quotient can be used to indicate the mixture stiffness. The higher the ratio, the stiffer the mixture is.

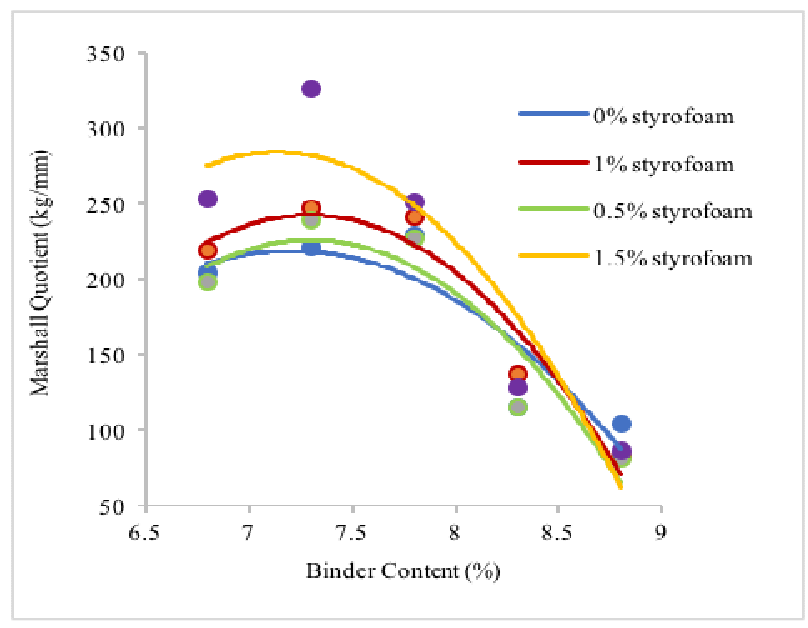

Fig.7 Marshall Quotient (kg/mm) vs. Binder Content (\%)

As can be seen from Fig. 7, as the Styrofoam Bitumen ratio increases the Marshall Quotient of the mixture are also increases. The higher the Styrofoam in the mixture, the higher the Marshall Quotient is. The highest the Marshall Quotient achieved at the $1.5 \%$ Styrofoam.

It is found that Marshall Quotient of the Styrofoam addition at $1.5 \%$ Styrofoam content in the bitumen is 1.5 times concerning the $0 \%$ Styrofoam. It can be inferred that these Styrofoam additions provide better resistance against permanent deformations due to their high stability and high 
Marshall Quotient and also indicate that these mixtures can be used in pavements where the solid bituminous mixture is required. Thus, the higher the Styrofoam in the mixture, the higher the stiffness of the mixture is.

\section{Void Filled with Bitumen (VFB)}

Void Filled with Bitumen is part of a space between aggregate minerals (VMAs) filled with asphalt effectively, expressed in percent. The minimum value of Voids Filled with Bitumen (VFB) is 70\% [5]. Most Department of Transportation specifications requires $70-80$ during the design phase [4]. In this investigation, the value of VFB is more than $70 \%$. It exceeds the minimum required, thus resulting in a low air void as seen in Fig. 8. Air void contents may be very critical regarding resisting permanent deformation. Thus, in this research, the VFB for all various Styrofoam in the mixture is sufficient to avoid rutting in heavy traffic situations.

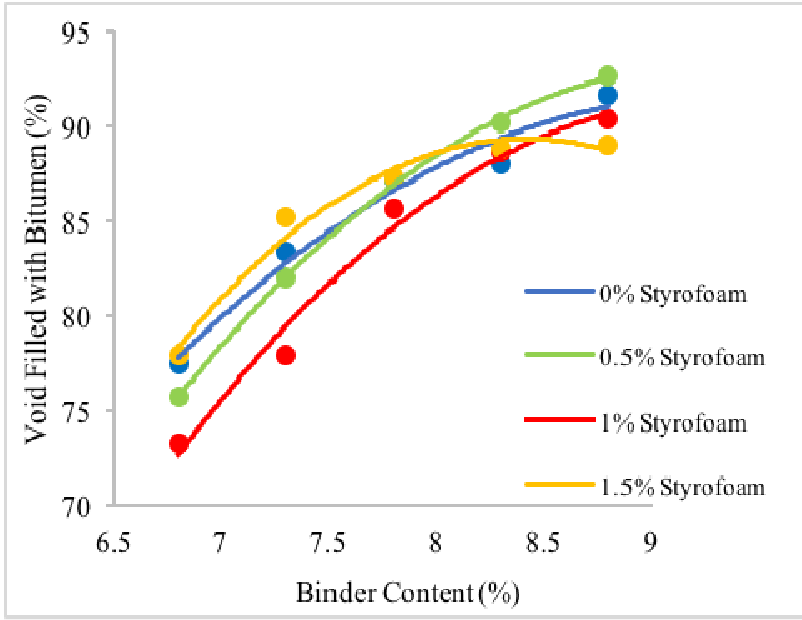

Fig.8 Void Filled with Bitumen (\%) vs. Binder Content (\%)

\section{E. Void in Mixture (VIM)}

Void in Mixture also known as air voids is the ratio of the volume of voids in a compacted mixture to the total compacted mixture volume [5].

The value of VIM may be influenced by compaction temperature, gradation, grade and type of pavement additive and the type or concentration of asphalt used. In this research the temperature, aggregate gradation and the type of asphalt used are not varied, thus the factors affecting the value of VIM only by the variation of Styrofoam and binder content.

Fig. 9 shows the voids in the total mix against the bitumen content for all various Styrofoam in bitumen. The voids are reduced as the percentage of Styrofoam increased.

Voids in Mix (VIM) should be in the range between $3.5 \%$ $-5.0 \%$. VIM is the total volume of air between the aggregate particles are covered with asphalt in a mixture which has been compacted and expressed as a percent of bulk volume. Optimum bitumen content should be in the interval of this figure [6]. It can be seen that the Void in Mixture for the Styrofoam added in bitumen are in the range of the voids content of the mixture. Unless the mixture without Styrofoam. The bitumen with Styrofoam has more voids than the mixture without Styrofoam.

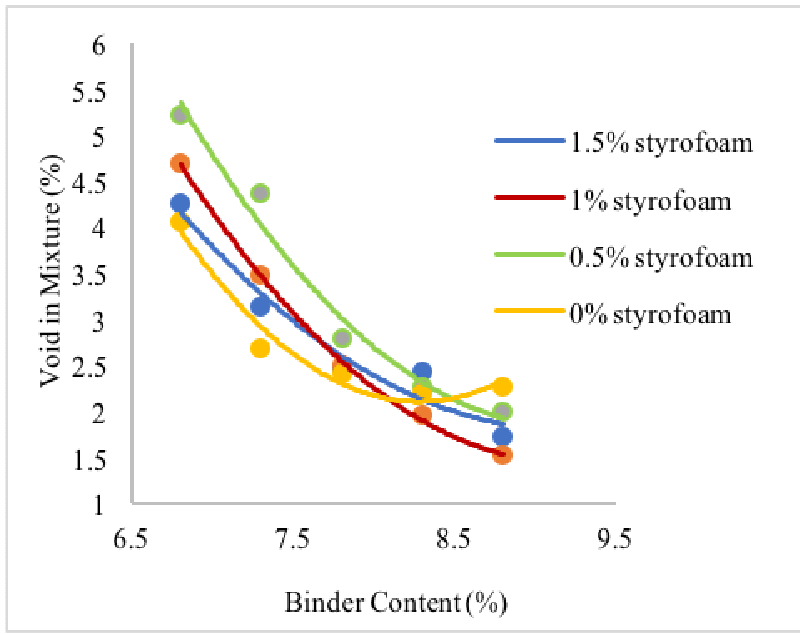

Fig.9 Void in Mixture (\%) vs. Binder Content (\%)

\section{F. Void In Mineral Aggregate (VMA)}

The void spaces between the aggregate particles of the compacted mix or VMA for the various Styrofoam addition is presented in Fig. 10. VMA is the sum of the air voids and the active asphalt content as per ASTM D6995 [15].

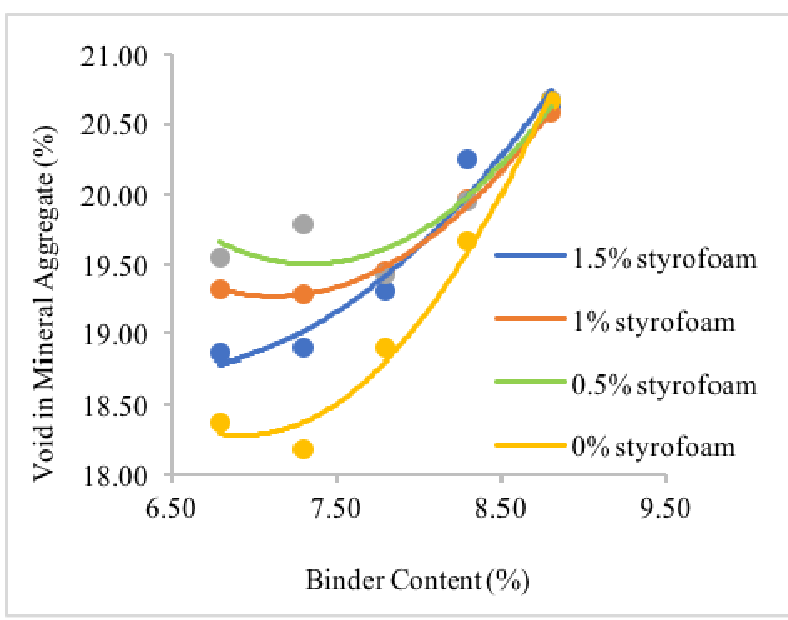

Fig.10 Void in Mineral Aggregate (\%) vs binder content (\%)

Fig. 10 shows the Void in Mineral Aggregate (VMA) against the binder content. Generally, the voids in mineral aggregate decrease with increasing Styrofoam in binder except for the 0\% Styrofoam. At lower binder content, the VMA at four different mixture of Styrofoam were widely varied.

The highest void is for the lesser content of Styrofoam in a binder, while the highest percentage of Styrofoam in a binder having the lower void, except for the 0\% Styrofoam. As the binder increasing the variations of VMA were continuously merging. It can be concluded that higher Styrofoam in binder reduces the VMA then it can reduce the oxidation thus it expects to increase the service life of the pavement. However, If the VMA is too low, it can be increased by modifying the gradation, asphalt content, or particle angularity. 


\section{CONCLUSIONS}

The properties of Styrofoam are found to be suitable as an additive for HRS-Base pavement. The higher the Styrofoam in the mixture, the higher the stability of the HRS-Base pavement is. The optimum bitumen content was $6.85 \%$ with $1.5 \%$ Styrofoam addition was resulted in the highest Stability. The Stability, bulk density increased with increase in the percentage of Styrofoam in the mix irrespective of the Styrofoam proportion and size. This indicates high stiffness. Thus, the use of Styrofoam in bitumen has produced a better result of Marshall Parameter, which having higher Stability, meet the required of Flow value, higher Marshall Quotient, lower Void in Mix. Consequently, it can solve the problem of Styrofoam waste disposal and environmental issue.

\section{ACKNOWLEDGMENT}

The authors would like to acknowledge the Faculty of Engineering, Andalas University, Padang, West Sumatera, Indonesia for funding this research. This research was supported under Contract. No. 030/UN.16.09D/PL/2017.

\section{REFERENCES}

[1] Health News, Styrofoam: Definition, Basic Ingredients, Uses, and Effects for Health, 17 November 2016

[2] Sims, B., Polystyrene Fact Sheet, Foundation for Advancements in Science and Education, Los Angeles, California, 2010.

[3] Tuates Jr.M.A, Caparino, O. A., "Development of Biodegradable Plastic as Mango Fruit Bag," International Journal of Advanced Science Engineering and Information Technology (IJASEIT), vol. 6, no. 5, 2016

[4] Tan Yeong Yu, Doh Shu Ing, Chin Siew Choo, Muhammad Aizat Azed, "Natural Lime Treated as Partial Cement Replacement to Produce Concrete," International Journal of Advanced Science Engineering and Information Technology (IJASEIT), vol. 7, no. 5, 2017

[5] 2010 specification $6^{\text {th }}$ division from Public Work Department standard in Indonesia (Kementrian Pekerjaan Umum Dirjen Bina Marga, Spesifikasi Umum, 2010)

[6] Slamet Widodo, Shen Hong, Abdelazim Ibrahim," Influence of Repeated Loading and Geosynthetic Reinforcement on Base Course
Thickness over Soft Soil," International Journal of Advanced Science Engineering and Information Technology (IJASEIT), vol. 2, no. 2, 2012

[7] Abd. Rahim Awang, Aminaton Marto, and Ahmad Maher Makhtar., "Morphological and Strength Properties of Tanjung Bin Coal Ash Mixtures for applied in Geotechnical Engineering Work," International Journal of Advanced Science Engineering and Information Technology (IJASEIT), vol. 2, no. 2, 2012

[8] Colorado Asphalt Pavement Association, Guideline for the Design and Use of Asphalt Pavements for Colorado Roadways, $2^{\text {nd }}$ Edition, January 2006

[9] AASHTO M 303-89, Standard Specification for Lime for Asphalt Mixtures, American Association of State and Highway Transportation Officials, 2010.

[10] Sukirman,S., Hot Mix Asphalt Concrete (Beton Aspal Campuran Panas) Bandung, 2010.

[11] Soandrijanie. J.F, Effect of Styrofoam on Stability and Marshall Value of Asphalt Concrete (Pengaruh Styrofoam Terhadap Stabilitas dan Nilai Marshall Beton Aspal), Konteks 5, Universitas Sumatera Utara, Medan, 2011.

[12] Mashuri and Batti. The Use of Waste Material for Asphalt Mixture (Pemanfaatan Material Limbah Pada Campuran Panas), Fakultas Teknik Universitas Tadulako, Palu, 2011.

[13] Saleh.M.S., Anggraini. R., Aquina. H., Characteristics of Porous Asphalt Mixture with Styrofoam Substitution on 60/70 Asphalt Penetration (Karakteristik Campuran Aspal Porus dengan Substitusi Styrofoam pada Aspal Penetrasi 60/70), Jurnal Teknik Sipil, Jurnal Teoretis dan Terapan Bidang Rekayasa Sipil, Vol.21 No. 3, ISSN 0853-2982, 2014

[14] ASTM D2872-12e1, Standard Test Method for Effect of Heat and Air on a Moving Film of Asphalt (Rolling Thin-Film Oven Test), ASTM International, West Conshohocken, PA, 2012

[15] ASTM D6995-05, Standard Test Method for Determining Field VMA based on the Maximum Specific Gravity of the Mix (Gmm), ASTM International, West Conshohocken, PA, 2005

[16] Setiawan. A., Suparma, L.B. and A. T. Mulyono, "Modelling Effect of Aggregate Gradation and Bitumen Content on Marshall Properties of Asphalt Concrete," International Journal of Advanced Science Engineering and Information Technology (IJASEIT), vol. 7, no. 2, 2017

[17] Tapkın, S. Improved Asphalt Aggregate Mix Properties by Portland Cement Modification. Master Thesis, Civil Engineering Department, Middle East Technical University, Ankara, Turkey, 1998

[18] Setiawan. A L.B. Suparma, and A. T. Mulyono, "The Effect of Aggregate Gradation on Workability of Asphalt Concrete," International Journal of Engineering and Technology (IJET), vol. 8, no. 4, pp. 1750-1757, Aug-Sept. 2016. 